\title{
Management of the Higher Education Institution in the Ethical Actions Context
}

\author{
Seweryn Cichoń \\ Czestochowa University of Technology, Czestochowa, Poland
}

\begin{abstract}
Managing the university in the context of ethics is one of many elements in the management of this specific organization. The task of university is functioning based on universal values, mission, vision, ethical codes, and responsibility and worthy behavior towards internal and external environment. In the era of globalization and constant changes, only a modernly managed higher education institution, acting according to principles of ethics, is able to meet requirements of surroundings. Behaviors of academic community should promote ethical actions in higher education institutions. It should be noted that the reputation, prestige in higher education, should also be based on the proceedings consistent with ethics.
\end{abstract}

Keywords: managing the higher education institutions, ethics, ethical actions, ethical code, ethical principles

\section{Introduction}

All of these activities, which occur in the process of higher education management, should be carried out according to ethical behavior.

Higher education institutions, more and more clearly, are becoming part of a course of socio-economic changes in our country and all over Europe. Universities must not only follow this trend, but in many cases, they should create it. Therefore, the management of a modern university comes not only to initiate the development of new technical and organizational solutions or improve the of teaching staff and the teaching process, but primarily it focuses on preparing students to work in a globalizing, integrating, and faster and faster changing economy. (Dworak \& Jaworski, 2011, p. 11)

University management is "formal and informal exercise of authority, in harmony with provisions, the politics and principles, which define the rights and responsibilities of various participants, including the rules for their cooperation and interaction" (Hirsch, Weber, \& Luc, 2001, p. 23). Ethical behavior associated with functioning of the higher education institutions is one of these rules.

The most important values in higher education are true, professionalism, responsibility, fairness, and non-combativeness.

Kloc and Chmielecka (2004) recognized certain dangers for higher education in relation to ethics. They claimed that,

Threats to the academic ethos result mainly from the decreasing role of the value in the academic and social life, as well as the increasingly widespread lack of concern for the common good-displaced by particular interests. Transfer to

Seweryn Cichoń, Ph.D., Czestochowa University of Technology, Czestochowa, Poland.

Correspondence concerning this article should be addressed to Seweryn Cichoń, ul. Liliowa 36, Czestochowa 42-200, Poland. E-mail: sew78@interia.pl. 
university life bad patterns from social environment; commercialization of education-visible in functioning of higher education institutions, as well as behaviors of their employees; lack of condemnation for breaking ethical standards-both in public life and in the academic community. (p. 9)

Therefore, it is necessary to do something to the ethos of higher education remained untouched.

\section{Ethics in the Organization-The Basic Issues}

Ethics is, by definition, the science of morality. Morality is a primitive notion and it does not have a definition. Researchers interested with this issue, trying to describe it as "a rational characteristic of every conscious and free human act and the perpetrator of this act-the human person" (Stępień, 1995, p. 104). Ethics is a set of standards which define what is right and wrong in human conduct (Bańko, 2007, p. 282).

According to the State Scientific Publishers Encyclopedia, ethics, in the colloquial sense, is the set of assessments and moral norms in a selected era and social communities or their specific system, i.e. the morality; in the philosophical sense, it is the science of morality, considered separately in two aspects: as a normative science of morality (so-called normative ethics) and descriptive-explanatory as the science of morality (descriptive ethics or ethology). Ethics in the normative aspect deals with establishing what is morally right and what is wrong. Based on accepted assessment and related duties, it determines directives-positive moral standards of conduct and indicating manners of transforming the widespread morality in order to adapt it to accepted moral ideal. Normative ethics is usually divided into: axiology (the theory of value) and deontology (the theory of duties). Ethics in the descriptive aspect is devoted to analyzing description and explanation of clarifying the adopted morality (widespread) in different ages and social environments, signposting sources, structure, and function of morality as a form of social awareness and detection of the correctness of its development (Dyczkowski, 2000). The literature identifies the issue of general ethics (fundamental) and specific ethics (Ślipko, 2002). The general ethics usually includes issues related to moral goods in correlation with being in a general sense; the specific ethics includes, in the strict sense, the subject of moral efficiency in relation to the moral person, as to itself, as the others (Migoń, 2013).

Relating ethics to the organization, the term of professional ethics is adopted, which could be defined as a set of norms appointing moral duties related to the occupation and professional social relations (Rawicz, 2007). Ethical codes do not provide ready solutions to all the dilemmas, which can be found in the work. Some decisions need to be taken independently, based on life and professional experience. The mission of professional ethics is to build a good image of the profession and enhance public confidence. The code of ethics is a measure that complements the legal provisions and creates a sense of responsibility for the consequence of activities (Czyżewicz, 2007).

\section{Role of Ethics in Organization Management}

Human resource management, in the context of ethics, is defined as "actions taken by the organization, which aim not only to increase the productivity and quality of work, but also to take into account the possibilities of staff and a variety of their needs and goals" (Moczydłowska, 2010, p. 220). In this kind of management, the principles of respect for human beings, mutual respect, procedural justice, transparency of taken actions during the taking employment, its duration, and termination must be applied (Kunecka, 2013). Ethics in the management of the organization is classified in three levels:

- as the attitude of the organization to the employee - determines behavior, adherence to ethical norms by 
manager, includes a recruitment and dismissal process, work and pay conditions, the scope of employee privacy, and mobbing;

- as the attitude of the employee to the organization, among others, a problem of the professional confidentiality and honesty;

- as the attitude of the company to other entities, which also depends on behavior of managers and their ethical norms; in relation to the consumer include upholding of the standards of products and services, in relation to other companies adherence to the principles of the fair competition, in relation to other organizations - honesty.

Authorities managing the organization are "people who can competently, professionally, and effectively carry out the functions of management, competently combining interests of the enterprise with the interests of its stakeholders, respecting the legal and ethical principles and of norms of the community life" (Kietliński, Reyes, \& Oleksyn, 2005, p. 197). Authorities avoid prescriptive style of leadership, especially when they are working with employees who are competent and have a high morale (Kietliński et al., 2005).

\section{Management of Ethical Activities in Higher Education}

The university authorities, fulfilling their professional duties, respect the ethical standards as an authority for the local environment, pupils, and students. They care about the high level of professional ethics of all the other people working in education. It is recognized that the university is a public or private good, serving the society. The main goal of action is a comprehensive development and upbringing of students. The university authorities are responsible for competent management of educational institution, in such a way as to satisfy the statutory objectives. This responsibility demands to comply with standards in the management, the teaching, and the upbringing. University managers have the following roles:

(1) as the goal of all actions put the students' good and development;

(2) integrate the university community, build relationships based on trust, kindness, and cooperation;

(3) inspire and create conditions for professional development of employees. Through self-development and improvement, workshop becomes a model for others;

(4) act fairly, honestly, and impartially;

(5) do their job with dignity and honor; prevent lowering its rank and authority;

(6) perform the guidelines of national education policy;

(7) apply laws and work for change of the ones, which badly serve the education;

(8) work for the establishment of standards of managerial work and act in accordance with them;

(9) increase the level of effectiveness of their subordinate their area of activities and make efforts to improve the education system;

(10) do not use their position for personal gain.

It is noted that the university ethical code allows to improve the trust between employer and employees, enhances the internal organizational culture, helps to resolve morally questionable conflicts, and thereby, takes care of the working environment. Surroundings receive the university orientated to ethical action as the organization worthy of trust, with the professional image and adequate reputation, which in effect has a positive impact on its efficient functioning (Gasparski \& Dietl, 2001).

The ethical code in the organization is inseparably connected with action, such as (Sroka, 2012):

- determination of value of the enterprise; 
- review of the organization in the context of ethics;

- review of politics, documents, and the organization's regulations;

- identification of the basic principles through the consultations with employees;

- development of a code of ethics with comments and explanations;

- development of policies for implementing the principles of the code of ethics;

- building ethical infrastructure, which allows employees to report about infringements;

- appointing the spokesman or spokesmen of ethics;

- providing training for employees;

- including principles of the ethics code in the scope of the internal audit, code of ethics constant communication.

Ethics in higher education refers both to the academic staff, doctoral students, and administrative employees and to the students. An example of ethical action at the university can be Czestochowa Technical University and its Ph.D. student code, which includes such tasks in the field of ethics as (Annex to the Resolution of the Senate of the Technical University of Czestochowa No. 333/2011/2012 dated on February 22, 2012):

- following the moral and ethical objectives universally adopted in the society;

- obeying all laws, in particular, the Act—Law on Higher Education, interior and other legal acts, which are applied at the university;

- constantly expand knowledge, improve scientific and teaching skills, aspire to the development of the own personality;

- respecting the laws and academic habits with one's behavior to take care of dignity and honor of Czestochowa University of Technology Ph.D. student;

- fulfilling duties which are included in the rules of doctoral studies:

(a) fairly and diligently carrying out research;

(b) complying with the rules of copyright and intellectual property rights protection;

(c) implementing the generally accepted ethical principles and communicating them to students during teaching activities;

(d) expressing views guided by the objective considerations of substantive;

(e) taking care of prestige and good image of the Technical University of Czestochowa and respecting its traditions;

(f) following the principles of solidarity with all members of the academic community;

(g) participating in social and organizational life of the university;

(h) applying and disseminating in the academic environment ethical values described in the code.

It is noticed that the university ethical code has many advantages (Gasparski \& Dietl, 2001):

- including in code, claims, and expectations as to specific behaviors of particular persons; motivating and confirming these persons in their proceedings;

- establishing long-term guidelines for correct and improper conduct;

- helping to solve problems especially in situations ethically questionable;

- provisions included in it, concerning not only employees of different levels, but also employers, which formed the basis of the values, principles, and rules of conduct. 
Therefore, it seems very important in university management that the basic principles and good manners were formulated in a precise way (it should go beyond the requirements of the common law and other regulations relating to university). There are 10 fundamental rules of the Code of good practices in higher education institutions (Szostek, 2007):

(1) Principle of the public service. According to the best academic tradition, universities are appointed for the completion of the mission of exploring and of promoting the truth. Rightly understanding the university culture requires that this mission was realized by pro bono activities. University, conscious of its significant social meaning, strives to, through the reliability of the research and the education of future cultural and political elite, contribute to accumulating the national common good and to reinforcing the mature democracy;

(2) Principle of impartiality in public affairs. The university has the privilege of being a respected institution of public life. A social great responsibility is involving with its functioning. It demands that when participating in the public life and especially speaking in significant socially matters, the university must be impartial and objective;

(3) Principle of legalism. Universities, in their activity, not only obey the law, as they are required in the state of law, but also they shape, among students and the entire academic community, a culture of respect for law and impartial applying principles and procedures, determined by the competent authorities. Also, possible discontent at the concerning the university regulations, accepted in the state, should be demonstrated in a way that complies with legal norms;

(4) Principle of autonomy and responsibility. The autonomy of the university, for which standards are defined by the act, includes the right to self-determination by the universities own mission and the consequent specific objectives and tasks, as well as many regulations. However, using its autonomy, university has to interpret the resulting entitlements in such a way that in the best style effectively operates in society for the benefit of the responsibility for the common good;

(5) Principle of separation and balance of power in the university. An important element of set of good practice in university management is legal and cultural rules for the implementation of the principle of balance and the division of competences among the rector as a single body, the senate as collegiate body, as well as peer tribunal and disciplinary committees, benefiting the possibility of independent judgment. Therefore, it should be emphasized that a rector and a senate are two independent and different bodies, none of which has authority over the other. Sign and proof of separation of these two authorities and their balance are statutory rules, according to which the rector neither indicates members of the senate, nor does the senate choose the rector; this is done by the competent authorities of the election. Fulfilling its tasks, both rector and the senate, should not only base on formal-legal conditions, but also refer to the conditions, resulting from the institutional culture of the university, which requires respect for the observance of good practice in the operation of both university bodies;

(6) Principle of creativity. Managing the university or its unit (faculty, institute, etc.) requires creativity. It does not allow to confine passively upholding the existing policies, but expresses itself in taking initiatives to develop the university. These initiatives must have strategic character and should also be taken responsibly and consistently strive to achieve tasks. They are determined by the university authorities, which take into consideration their substantive importance, financial and personnel possibilities, as well as the perspective of cooperation with other entities. Previously certified ability to be creative should be an important criterion in the choices or the competitions for managerial positions; 
(7) Principle of transparency. To consolidate the university reliability, especially in the rational use of resources and to avoid nepotism, corruption, and other cases of abusing power, it is necessary for all procedures related to the tasks and education or research initiatives, competitions for positions, promotions and rewards employees, and recruitment and promotion of students to be open and just;

(8) Principle of subsidiary. The authorities should respect the principle of subsidiary, which obliges to respect the competences and initiatives of lower authorities and individual employees. This principle obliges everyone to observe the official channels in dealing with matters, always with the right to the appeal at settling of matters of contention. The appeal authority is obliged to timely and factual response to the objections raised by the employees;

(9) Principle of the respect for the dignity and tolerance. Bearing in mind the dignity and reputation of all members of the academic community, universities follow the principles of trust, respect, and tolerance for all permitted by law ideas, attitudes, and lifestyles. The right to privacy is respected and conflicts are resolved through discussion between the sides, which treat each other with respect and accept their rights;

(10) The principle of the universality of research and education. The traditional and contemporary mission of the university requires it to be a public institution, through research and education including achievements of world science and concern for the good of all mankind. Universities should increase the number of international contacts and aspire for providing the right place for themselves in the international academic community.

\section{Conclusions}

Institutions of higher education is one of the oldest forms of organization in the world. One of the values that universities contributed to the development of civilization is their organizational and cultural legacy. However, to remain and act as efficient and reliable organization, which serves many important functions in society, contemporary universities must take care of its reputation and research position in accordance with modern concepts of management of the organization (Mizera, 2011).

The university authorities, in the management of ethical actions in this specific organization, must be competent and well cope with internal and external contacts - with the environment, to achieve ranks on high places in rankings of higher education institutions (Mizera, 2011).

Only ethical conduct in the whole structure of the university, from authorities to students can provide a coherent system of its operation. Students existing in ethical university surroundings will be able, in the future, to fill up civil and professional tasks in the building the knowledge and the morality society. The strategic role in this aspect is assigned to the university authorities and academic teachers (Fullan, 2006). During functioning amongst norms, expectations, and the values, they should: (1) serve the truth, the justice, the freedom, and the partnership; (2) stimulate attitudes and aspirations, which promote scientific, social, and technical progress, guided by integrity in the performance of duties related to science and teaching; and (3) work on the scientific and pedagogical improvement of students (Kiedrowicz, 2004). Effective academic teacher during classes should try not only to transmit the knowledge, but also to allow its use in practical terms, in accordance with the principles of ethical conduct (Cichoń, 2013). Effective management of the university (in the organizational, socio-economic, process, quality, marketing, ethical, oriented to the knowledge, and the value aspect) is a determinant of dealing with a changing environment. 


\section{References}

Bańko, M. (2007). Polish language dictionary. Warszawa: Wydawnictwo State Scientofic Publishers.

Cichoń, S. (2013). The quality of higher education. Częstochowa: Wydawnictwo Politechniki Częstochowskiej.

Czyżewicz, K. (2007). Legal and ethical aspects of mental health care. In R. E. Wilczek (Ed.), Basics of psychiatric nursing. Lublin: Wydawnictwo Czelej sp. z o.o.

Dworak, J., \& Jaworski, J. (2011). Management of university. Dilemmas and challenges. Gdańsk: Wydawnictwo Wyższej Szkoły Bankowej w Gdańsku.

Dyczkowski, A. (2000). Philosophy. Warszawa: Wydawnictwo PWN.

Fullan, M. (2006). Responsible and effective management of the school. Warszawa: PWN.

Gasparski, W., \& Dietl, J. (2001). Business ethics in action. Warszawa: PWN.

Hirsch, W., Weber, Z., \& Luc, E. (2001). Governance in higher education. London: Economica Ltd.

Kiedrowicz, G. (2004). Role of the university teacher in shaping the values system of students (Pedagogy of the higher education institution, 23/2004, Szczecin-Warszawa, Wydawnictwo Naukowe Uniwersytetu Szczecińśkiego).

Kietliński, K., Reyes, V. M., \& Oleksyn, T. (2005). Ethics in business and management. Kraków: Wydawnictwo Oficyny Ekonomicznej.

Kloc, K., \& Chmielecka, E. (2004). Good manners in academic education. Warszawa: Wydawnictwo Fundacji Promocji i Akredytacji Kierunków Ekonomicznych.

Kunecka, D. (2013). Ethical dilemmas in human resource management on the example of health sector. Modern Management, 2, 101-102.

Migoń, M. (2013). Introduction to ethics. Gdańsk: Wydawnictwo Gdańskiej Szkoły Wyższej.

Mizera, K. (2011). Codes of ethics on the basis of academic circles. In J. Dworak and J. Jaworski (Eds.), Management of university. Dilemmas and challenges. Gdańsk: Wydawnictwo Wyższej Szkoły Bankowej w Gdańsku.

Moczydłowska, J. (2010). Human resource management in the organization. Academic guide. Warszawa: Wydawnictwo Difin.

Rawicz, J. (2007). Encyclopedia. Warszawa: Wydawnictwo PWN.

Ślipko, T. (2002). An outline of general ethics. Kraków: Wydawnictwo WAM.

Sroka, R. (2012). Model behaviours. The Staff and the Management, 1, 38.

Stępień, A. B. (1995). Introduction to philosophy. Lublin: Wydawnictwo TN KUL.

Szostek, A. (2007). Code of best practices at higher education institutions (conference materials of Rectors of Polish Academic Schools, Foundation of Polish Rectors, Wydawnictwo Fundacji dla Uniwersytetu Jagiellońskiego, Kraków). 